\title{
Pharmacy, nursing, and physician assistant studies student self-report and perceptions regarding classroom etiquette
}

\author{
Eytan A. Klausner ${ }^{1}$, Kandi D. Pitchford ${ }^{2}$, James L. Schmidhammer ${ }^{3}$, Billie R. Phillips ${ }^{4,5}$ \\ ${ }^{1}$ South College School of Pharmacy, Knoxville, Tennessee, USA \\ ${ }^{2}$ South College School of Physician Assistant Studies, Knoxville, Tennessee, USA \\ ${ }^{3}$ University of Tennessee at Knoxville, Knoxville, Tennessee, USA \\ ${ }^{4}$ South College School of Nursing, Knoxville, Tennessee, USA \\ ${ }^{5}$ Phillips Consulting, LLC, Knoxville, Tennessee, USA
}

\section{Keywords}

Classroom civility

Classroom etiquette

Cyber slacking

Non-academic classroom activity

Respectful classroom environment

Student incivility

\section{Correspondence}

Eytan A. Klausner, BPharm, PhD Associate Professor of Pharmaceutical Sciences Department of Pharmaceutical Sciences South College School of Pharmacy Knoxville

TN 37922

eklausner@south.edu

\begin{abstract}
Introduction: The study aimed to investigate pharmacy, physician assistant studies, and nursing students' self-report regarding their classroom etiquette and perceptions regarding classroom etiquette. Methods: A survey regarding classroom etiquette was administered to first year pharmacy, physician assistant studies, and nursing students. Statistical analysis was performed to determine differences among various student behaviors and perceptions, and among students of the three academic programmes. Results: Most students ( $>84 \%)$ indicated that arriving late to class, leaving the classroom during lecture without returning, initiating a conversation with a peer during lecture, and conducting non-class-related activities with electronic devices during lecture are unprofessional. Students selfreported that tardiness and leaving and returning to the classroom during lecture are not rare. Most students (52\%) indicated that it is acceptable to have a conversation with a peer while the professor is teaching if the conversation is directly related to the lecture material. Some students $(27 \%)$ indicated that the non-classrelated activities that they conduct during lecture using their laptop or tablet device affected their academic performance. More students reported their academic performance is adversely affected by non-academic use of laptop or tablet device compared to the use of cell phones. Conclusion: This study suggests there are opportunities to improve student classroom etiquette in various academic settings. Moreover, it may bring a greater awareness to the issue of classroom etiquette, and thereby encourage faculty and administration to evaluate, and/or better enforce policies related to classroom etiquette.
\end{abstract}

\section{Introduction}

Traditionally in higher education, a primary role of college instructors is to educate students on a specific subject matter. To meet this objective, instructors are expected to establish and maintain appropriate classroom etiquette (Flanigan \& Kiewra, 2018). When appropriate classroom etiquette is maintained, students behave in a civil manner that facilitates self-learning and does not interfere with other student learning or with the instruction (Tom, 1998). It has been suggested that student engagement in uncivil behaviours such as tardiness and the non-academic use of electronic devices 
during class may directly interfere with self-learning and other student's learning (Sana, Weston, \& Cepeda, 2013; Gaudreau, Miranda, \& Gareau, 2014; Aagaard, 2015; Taneja, Fiore, \& Fischer, 2015). Additionally, it may adversely affect class instruction (Feldmann, 2001; Morrissette, 2001; Wei, Wang, \& Klausner, 2012). Such conduct shifts the instructor's attention from the subject matter toward the disruptive behaviour and the appropriate way to address it (Ali \& Smith, 2014).

In recent decades technological advancements have transformed the classroom, as most students in contemporary classrooms are equipped with at least one and usually more than one electronic device that may support learning (Sana et al., 2013). For example, a laptop can support note-taking (Spies, 2010; Sana et al., 2013; Spallek \& von Bergmann, 2014; Aagaard, 2015), and smartphones can facilitate student engagement and polling (Imazeki, 2014; Pistilli \& Cain, 2016; Ma et al., 2018). In addition, many institutions video record classes to benefit students who are unable to attend class and support students who need to review class material (Bos et al., 2016). However, there are several disadvantages to using electronic devices and technology in the classroom. For example, instantaneous and convenient access to the internet, email, and social media can distract students (Sana et al., 2013). Students may feel free or obligated to make or respond to phone calls or text messages during class time (Sana et al., 2013; Burke et al., 2014; Miller et al., 2014). Furthermore, the availability of video recordings may obviate the need to attend class or reduce the need to pay attention to the instructor (Bos et al., 2016; Kwiatkowski \& Demirbilek, 2016; O'Callaghan et al., 2017).

Challenges to the maintenance of appropriate classroom etiquette are not new and predate the technological advancements that laid the foundations for the contemporary classroom (Emerick, 1994; Wright, Perry, \& Barnett, 2011; Knepp, 2012; Burke et al., 2014; Pistilli \& Cain, 2016; Flanigan \& Kiewra, 2018). However, classroom distractions that stem from non-academic uses of electronic devices may compound, rather than replace, other unprofessional behaviours (Miller et al., 2014; Pistilli \& Cain, 2016; Flanigan \& Kiewra, 2018). According to some reports, faculty perceive that classroom distractions are becoming more common (Knepp, 2012; Clark, 2017).

Creating and maintaining appropriate classroom etiquette requires a better understanding of the nature and extent of unprofessional student behaviours and student perceptions about professional and unprofessional behaviours. Studies reported in the literature about classroom etiquette have been conducted in various disciplines, including radiography (Clark, 2017), nursing (Suplee et al., 2008), business
(Burke et al., 2014), and social work (Ausbrooks, Jones, \& Tijerina, 2011). However, the authors were unable to locate any studies in the existing literature that 1 ) compared the classroom etiquette across multiple disciplines, especially in healthcare professions; or 2) examined student self-report regarding their familiarity with the concept of classroom etiquette, the extent of discourteous student behaviour in the classroom, and its possible effect on learning.

Therefore, the major aim of the study was to investigate pharmacy, physician assistant studies (PA), and nursing students' self-report regarding their classroom etiquette and their perceptions regarding classroom etiquette. Areas of classroom etiquette the study aimed to investigate included 1) student perceptions about classroom professionalism; 2) student arrival to class on time and remaining seated during class time; 3) student discussions during lecture; and 4) non-academic uses of electronic devices in the classroom. The information obtained from the study regarding classroom etiquette in various academic programs may provide instructors with a greater awareness of classroom etiquette from the students' perspective. This may encourage instructors to better create classroom environments that are conducive to student learning.

\section{Methods}

\section{Survey instrument}

The study design was based on a survey instrument that aimed to investigate students about various aspects of classroom etiquette. A literature review that considered articles in the field identified a few relevant and fine survey instruments (Paik \& Broedel-Zaugg, 2006; Sana et al., 2013; Gaudreau et al., 2014); however, none of the survey instruments directly addressed the aims of the study. Hence, a survey instrument was designed by the principal investigator. The survey instrument was reviewed by the co-authors for content validity of the items, with a subsequent discussion between the authors and implementation of changes as discussed. Next, a draft of the survey instrument was shared with five other faculty members and one student for further suggestions for improvement. All authors reviewed the feedback provided, and it was collectively decided which recommendations to implement.

The survey questions appear in Table I to Table VI. The survey encompassed major domains in classroom etiquette such as tardiness, leaving class early, student discussions during lecture (Emerick, 1994; Paik \& Broedel-Zaugg, 2006; AlKandari, 2011; Clark, 2017), and cyberslacking (Taneja et al., 2015; Clark, 2017; Flanigan \& Kiewra, 2018). 


\section{Survey approval and administration}

The study protocol was approved by the Institutional Review Board (IRB) of South College. First-year students from pharmacy $(n=81$, studying toward a Doctor of Pharmacy), PA ( $n=77$, studying toward a Master of Health Science in Physician Assistant Studies), and nursing ( $n=34$, studying toward a Bachelor of Science in Nursing) programmes from South College were invited to participate in the study. These programmes were chosen for the study because they represent healthcare programmes that lead to degrees of various educational levels: Doctoral degree, master's degree, and bachelor's degree. In addition, these programmes are the only onground health programmes of South College that lead to a bachelor's degree or higher. Surveys for students from the three programmes were administered with a convenience sampling technique to students who started their academic programme in the summer or autumn of 2017. Surveys were administered via Qualtrics during the last three weeks of the third quarter of each programme: In March 2018 for pharmacy students and in June 2018 for PA and nursing students. Pharmacy students were allotted time to complete the survey during class time, whereas PA and nursing students completed the survey as an extra-curricular activity. Pharmacy and PA students who completed the survey were given extra credit in a course. Nursing students who completed the survey were given a nominal gift card. Only students who provided written consent were enrolled in the study.

\section{Statistical analysis}

Statistical analyses of ordinal data were performed using the Chi-square test for trend. Such data can be seen in Table I Question 3, Table II Question 2, Table III Questions
1-3, Table IV Questions 1-2, and Table V and Table VI Question 1. Statistical analyses of categorical data were performed using Fisher's exact test. The analysis of continuous data to identify differences in the ages between students of the three programmes (Table I Question 1) was conducted using Analysis of Variance with subsequent Tukey-Kramer multiple comparisons test. GraphPad InStat (GraphPad Software, La Jolla, CA, USA) was used for analyses of continuous data and ordinal data and to conduct Fisher's exact test where categorical data could be presented as a $2 \times 2$ contingency table. Categorical data that required presentation as a larger contingency table were analyzed using Fisher's exact test in SAS (SAS Institute Inc., Cary, NC, USA). In the data analysis, a statistical significance was set at $p<0.05$.

\section{Results}

\section{Demographic information of student populations and response rates}

Demographic information of student populations and response rates are presented in Table I. Students from pharmacy, PA, and nursing programmes had the same median age of 24 years. However, the average nursing student was three years older $(p<0.05)$ than pharmacy and PA students, a finding that was due to the influence of several older students. There was a significant difference $(p<0.05)$ in the academic background of students in different academic programmes as the PA programme requires a bachelor's degree as a prerequisite for admissions into the programme, whereas the pharmacy and nursing programmes do not. The overall response rate was $79 \%$.

Table I: Demographic information of student populations and response rates

\begin{tabular}{|c|c|c|c|c|c|}
\hline \multicolumn{2}{|l|}{ Question } & Pharmacy & PA & Nursing & All responders \\
\hline \multicolumn{2}{|c|}{ 1. Age (mean (standard deviation), median)* } & $25(3), 24$ & $25(2), 24$ & $28(8), 24$ & $25(4), 24$ \\
\hline \multicolumn{2}{|c|}{ 2. Females in class, $\%^{+}$} & 62 & 81 & 87 & 72 \\
\hline \multirow[t]{3}{*}{ 3. Highest academic degree, $\%^{\ddagger}$} & $\begin{array}{l}\text { Associate degree or no } \\
\text { degree }\end{array}$ & 41 & 0 & 61 & 29 \\
\hline & Bachelor's degree & 57 & 93 & 39 & 67 \\
\hline & $\begin{array}{l}\text { Master's degree or doctoral } \\
\text { degree }\end{array}$ & 3 & 7 & 0 & 4 \\
\hline \multicolumn{2}{|c|}{ 4. Response rate, $\%$ (number of responders) } & $94(76)$ & $74(57)$ & $67(23)$ & $79(156)$ \\
\hline
\end{tabular}

\section{Perceptions about professionalism and student familiarity with the concept of classroom etiquette}

Perceptions about professionalism and student familiarity with the concept of classroom etiquette are presented in Table II. Most students (77\%) heard about the concept of classroom etiquette after they started their programme at South College. In addition, most students $(77 \%)$ heard about the concept of classroom etiquette during the four years before they started their professional programme at South College. Only a 
small proportion of students $(\leq 16 \%)$ indicated that arriving late to class, leaving the classroom during lecture without returning, initiating a conversation with a peer during lecture, or conducting non-class-related activities during lecture, are professional behaviours.

Table II: Perceptions about professionalism and student familiarity with the concept of classroom etiquette

\begin{tabular}{|c|c|c|c|c|c|}
\hline \multicolumn{2}{|l|}{ Question } & Pharmacy & PA & Nursing & All responders \\
\hline \multicolumn{2}{|c|}{$\begin{array}{l}\text { 1. Percent of students who heard about the concept of classroom } \\
\text { etiquette after they started their professional program with South College }\end{array}$} & 77 & 84 & 61 & 77 \\
\hline 2. Prior to starting your professional program with & 1 year & 42 & 30 & 43 & 38 \\
\hline South College, when was the last time the concept & 2 years & 17 & 28 & 9 & 19 \\
\hline of classroom etiquette was introduced or & $3-4$ years & 17 & 19 & 35 & 20 \\
\hline reinforced to you? (\%) & 5 years or longer & 24 & 23 & 13 & 22 \\
\hline \multicolumn{6}{|c|}{$\begin{array}{l}\text { 3. Indicate whether the activities below are professional or unprofessional } \\
\text { (\% professional) }\end{array}$} \\
\hline \multicolumn{2}{|l|}{ 3a. Arriving late to class } & 4 & 4 & 0 & 3 \\
\hline \multicolumn{2}{|c|}{$\begin{array}{l}\text { 3b. Leaving the classroom during lecture without returning (not due to } \\
\text { extenuating circumstances) }\end{array}$} & 11 & 4 & 0 & 6 \\
\hline \multicolumn{2}{|l|}{ 3c. Initiating a conversation with a peer during lecture* } & 24 & 11 & 4 & 16 \\
\hline \multicolumn{2}{|c|}{$\begin{array}{l}\text { 3d. Conducting non-class-related activities (e.g., with laptop, tablet } \\
\text { device, or cell phone) during lecture }\end{array}$} & 14 & 5 & 0 & 8 \\
\hline
\end{tabular}

\section{Student arrival to class on time and remaining seated during class time}

Student perspectives regarding arrival to class on time and remaining seated during class time are presented in Table III. A large proportion of students (42\%, Question 1) arrive late to class at least once or twice every quarter (this number combined $11 \%$ of students who arrive late to class at least once every 2-3 weeks with $31 \%$ of students who arrive late to class once or twice every quarter). The frequency of late arrival to class was greater $(p<0.05)$ for pharmacy students than for PA students. Most students (77\%) indicated that they leave and return to the classroom at least once or twice every quarter. Only a small proportion of students (15\%) leave the classroom prior to the end of the lecture and do not return at a frequency of at least once or twice every quarter.

Table III: Student arrival to class on time and remaining seated during class time

\begin{tabular}{|c|c|c|c|c|c|}
\hline Question & Answer choice & Pharmacy & PA & Nursing & All responders \\
\hline \multirow[t]{3}{*}{$\begin{array}{l}\text { 1. How frequently do you arrive late to } \\
\text { class? }(\%)^{*}\end{array}$} & $\begin{array}{l}\text { At least once every } 2-3 \\
\text { weeks }\end{array}$ & 14 & 9 & 8 & 11 \\
\hline & $\begin{array}{l}\text { Once or twice every } \\
\text { quarter }\end{array}$ & 40 & 19 & 33 & 31 \\
\hline & Never & 46 & 72 & 58 & 58 \\
\hline \multirow[t]{3}{*}{$\begin{array}{l}\text { 2. How frequently do you leave and return } \\
\text { to the classroom during lecture? (\%) }\end{array}$} & $\begin{array}{l}\text { At least once every } 2-3 \\
\text { weeks }\end{array}$ & 41 & 51 & 26 & 42 \\
\hline & $\begin{array}{l}\text { Once or twice every } \\
\text { quarter }\end{array}$ & 33 & 30 & 57 & 35 \\
\hline & Never & 26 & 19 & 17 & 22 \\
\hline \multirow{3}{*}{$\begin{array}{l}\text { 3. How frequently do you leave the } \\
\text { classroom prior to the end of the lecture and } \\
\text { not return? }(\%)^{*}\end{array}$} & $\begin{array}{l}\text { At least once every } 2-3 \\
\text { weeks }\end{array}$ & 11 & 0 & 4 & 6 \\
\hline & $\begin{array}{l}\text { Once or twice every } \\
\text { quarter }\end{array}$ & 14 & 4 & 9 & 9 \\
\hline & Never & 75 & 96 & 87 & 84 \\
\hline \multicolumn{2}{|c|}{$\begin{array}{l}\text { 4. Do you think that a student who arrives late to class interferes with the } \\
\text { learning process of their peers? (\% who responded yes) }\end{array}$} & 51 & 68 & 61 & 59 \\
\hline \multicolumn{2}{|c|}{$\begin{array}{l}\text { 5. Do you think that a student who leaves the classroom during lecture } \\
\text { interferes with the learning process of their peers? (\% who responded } \\
\text { yes) }\end{array}$} & 37 & 40 & 39 & 38 \\
\hline
\end{tabular}




\section{Student discussions during lecture}

Student perspectives regarding discussions that occur during lecture are presented in Table IV. Most students (70\%) initiate a conversation with a peer during lecture at least once a week. The frequency that pharmacy students report that a peer initiates a conversation with them was greater $(p<0.05)$ than the corresponding reports by PA students and nursing students. Most students (52\%) indicated it is acceptable to have a conversation with a peer while the professor is teaching if the conversation is directly related to the lecture material. Most students indicated if they initiate a conversation with a peer during lecture that the conversation disturbs their peer (66\%), and a conversation among two or more students that takes place within their vicinity during lecture interferes with their own learning process (68\%). The proportion of nursing students who indicated a conversation between two or more students that takes place in their vicinity during lecture, interferes with their learning process or disturbs other classmates in their immediate vicinity was significantly greater $(p<0.05)$ than the proportion of pharmacy students or PA students who had the same perception.

Table IV: Student discussions during lecture

\begin{tabular}{|c|c|c|c|c|c|}
\hline Question & Answer choice & Pharmacy & PA & Nursing & All responders \\
\hline $\begin{array}{l}\text { 1. How frequently do you initiate a } \\
\text { conversation with a peer during lecture? }\end{array}$ & $\begin{array}{l}\text { At least a few (2-3) times a } \\
\text { day }\end{array}$ & 26 & 16 & 9 & 20 \\
\hline \multirow[t]{3}{*}{ (\%) } & $\begin{array}{l}\text { Once a day or once every } \\
\text { few }(2-3) \text { days }\end{array}$ & 26 & 25 & 17 & 24 \\
\hline & Approximately once a week & 26 & 26 & 26 & 26 \\
\hline & Never & 23 & 33 & 48 & 30 \\
\hline \multirow[t]{4}{*}{$\begin{array}{l}\text { 2. During lecture, how frequently does a } \\
\text { peer initiate a conversation with you? }(\%)^{*}\end{array}$} & $\begin{array}{l}\text { At least a few (2-3) times a } \\
\text { day }\end{array}$ & 38 & 23 & 22 & 30 \\
\hline & $\begin{array}{l}\text { Once a day or once every } \\
\text { few }(2-3) \text { days }\end{array}$ & 36 & 28 & 13 & 30 \\
\hline & Approximately once a week & 14 & 33 & 39 & 25 \\
\hline & Never & 12 & 16 & 26 & 15 \\
\hline 3. Is it acceptable to have a conversation & Yes & 5 & 2 & 0 & 3 \\
\hline \multirow[t]{2}{*}{$\begin{array}{l}\text { with a peer while the professor is } \\
\text { teaching? }(\%)\end{array}$} & $\begin{array}{l}\text { Only if the conversation is } \\
\text { directly related to the } \\
\text { lecture material }\end{array}$ & 51 & 51 & 58 & 52 \\
\hline & No & 44 & 47 & 42 & 45 \\
\hline \multicolumn{2}{|c|}{$\begin{array}{l}\text { 4. If you initiate a conversation with a peer during lecture do you think } \\
\text { that it disturbs that peer? (\% who responded yes) }\end{array}$} & 63 & 67 & 74 & 66 \\
\hline \multicolumn{2}{|c|}{$\begin{array}{l}\text { 5. Do you think that a conversation between two or more students that } \\
\text { takes place in your vicinity, during lecture, interferes with your learning } \\
\text { process? (\% who responded yes) })^{\dagger}\end{array}$} & 62 & 68 & 91 & 68 \\
\hline \multicolumn{2}{|c|}{$\begin{array}{l}\text { 6. If you initiate a conversation with a peer during lecture do you think } \\
\text { that it disturbs other classmates in your immediate vicinity? (\% who } \\
\text { responded yes) }\end{array}$} & 62 & 71 & 96 & 70 \\
\hline
\end{tabular}

\section{Non-academic uses of laptop and tablet device in the classroom}

Student perspectives regarding non-academic uses of laptop and tablet device in the classrooms are presented in Table V. Eighty-one per cent of students use laptop and tablet device for non-academic purposes in the classroom at least once every two to three days or approximately once a week. Twentyseven per cent of students indicated that non-classrelated activities they conduct during lecture with their laptop or tablet device affect their academic performance. Twenty-five per cent of students indicated that non-class-related activities a peer conducts in their immediate vicinity with their laptop or tablet device affects their academic performance, or the non-class-related activities they conduct during lecture may affect their peers.

Among all the mentioned comparisons for Table $\mathrm{V}$, there were significant differences $(p<0.05)$ between pharmacy, PA, and nursing students. The frequency of nursing students who reported they use their laptop or tablet device for non-class-related activities during lecture was significantly smaller $(p<0.05)$ compared to corresponding responses from pharmacy or PA students. Compared to PA or nursing students, a significantly smaller $(p<0.05)$ proportion of pharmacy 
students (22\%) indicated that non-class-related activities they conduct during lecture using laptop or tablet device affect their academic performance. Compared to pharmacy or PA students, a significantly greater $(p<0.05)$ proportion of nursing students $(54 \%)$ indicated that non-class-related use of laptop or tablet device by a peer in their immediate vicinity affects their academic performance; similarly, a significantly greater $(p<0.05)$ proportion of nursing students $(35 \%)$ indicated that their use of laptop or tablet device during lecture for non-class-related activities may disturb their peer(s).

Table V: Non-academic uses of laptop and tablet device in the classroom

\begin{tabular}{|c|c|c|c|c|c|}
\hline Question & Answer choice & Pharmacy & PA & Nursing & All responders \\
\hline 1. How frequently do you use your laptop or & At least once a day & 52 & 65 & 17 & 52 \\
\hline $\begin{array}{l}\text { tablet device for non-class-related activities } \\
\text { (e.g., Facebook, email, shopping) during }\end{array}$ & $\begin{array}{l}\text { Once every } 2-3 \text { days or } \\
\text { approximately one a week }\end{array}$ & 22 & 33 & 43 & 29 \\
\hline lecture? (\%)* & Never & 27 & 2 & 39 & 19 \\
\hline 2. Do you think that the non-class-related & Yes & 22 & 32 & 32 & 27 \\
\hline activities (e.g., web surfing, checking email, & No & 60 & 65 & 23 & 56 \\
\hline $\begin{array}{l}\text { social media) that you conduct during } \\
\text { lecture using your laptop or tablet device } \\
\text { affects your academic performance? (\%)* }\end{array}$ & $\begin{array}{l}\text { I don't conduct non-class- } \\
\text { related computer activities } \\
\text { during lecture }\end{array}$ & 18 & 3 & 45 & 17 \\
\hline 3. Do you think that the non-class-related & Yes & 18 & 23 & 54 & 25 \\
\hline activities that a peer in your immediate & No & 77 & 75 & 46 & 72 \\
\hline $\begin{array}{l}\text { vicinity conducts during lecture with their } \\
\text { laptop or tablet device affects your academic } \\
\text { performance? }(\%)^{*}\end{array}$ & $\begin{array}{l}\text { My neighbors don't conduct } \\
\text { non-class-related computer } \\
\text { activities during lecture }\end{array}$ & 5 & 2 & 0 & 3 \\
\hline 4. Do you think that the non-class-related & Yes & 19 & 28 & 35 & 25 \\
\hline activities that you conduct during lecture & No & 63 & 68 & 30 & 60 \\
\hline $\begin{array}{l}\text { with your laptop or tablet device may disturb } \\
\text { your peer(s)? (\%)* }\end{array}$ & $\begin{array}{l}\text { I don't conduct non-class- } \\
\text { related computer activities } \\
\text { during lecture }\end{array}$ & 18 & 4 & 35 & 15 \\
\hline
\end{tabular}

* Students from each program are different from students from the other programs, $p<0.05$

\section{Non-academic uses of cell phones in the classroom}

Student perspectives regarding non-academic uses of cell phones in the classroom are presented in Table VI. Sixty-four per cent of students use cell phones for nonacademic activities in the classroom at least once every two to three days or approximately once a week. Eighteen per cent of students indicated that their use of cell phones during lecture for non-class-related activities affects their own academic performance. Seventeen per cent of students indicated that the use of cell phones by a peer in their immediate vicinity for non-class-related activities affects their academic performance. Eleven per cent of students indicated that their own use of a cell phone for non-class-related activities during lecture may affect their peers.

When taken together, the data in Table VI indicate that there were significant differences $(p<0.05)$ between PA students, and pharmacy or nursing students. The frequency that PA students reported they use their cell phones for non-class-related activities during lecture was significantly smaller $(p<0.05)$ compared to such reports by pharmacy or nursing students. Compared to nursing students, a significantly smaller $(p<0.05)$ proportion of PA students indicated a) the non-class- related activities they conduct during lecture using their cell phones affects their academic performance; b) the non-class-related activities conducted by a peer in their vicinity with their cell phone affects their academic performance; and c) the non-class-related activities they conduct during lecture with their cell phone may disturb their peer(s).

\section{Discussion}

Most reports in the literature regarding classroom etiquette discuss either traditional aspects of classroom etiquette such as student discussions during lecture (Ziefle, 2018) or non-academic-uses of electronic devices (Sana et al., 2013; Gaudreau et al., 2014). The present study is unique because it marries traditional aspects of classroom etiquette and nonacademic uses of electronic devices into one theme. Another unique aspect is the comparison between student practices and perceptions regarding classroom etiquette of three different healthcare programmes from the same institution. 
Table VI: Non-academic uses of cell phones in the classroom

\begin{tabular}{|c|c|c|c|c|c|}
\hline Question & Answer choice & Pharmacy & PA & Nursing & All responders \\
\hline 1. How frequently do you use your cell & At least once a day & 55 & 25 & 39 & 42 \\
\hline $\begin{array}{l}\text { phone for non-class-related activities (e.g., } \\
\text { Facebook, email, shopping) during lecture? }\end{array}$ & $\begin{array}{l}\text { Once every 2-3 days or } \\
\text { approximately one a week }\end{array}$ & 27 & 9 & 39 & 22 \\
\hline$(\%)^{*}$ & Never & 18 & 67 & 22 & 36 \\
\hline 2. Do you think the non-class-related & Yes & 15 & 10 & 48 & 18 \\
\hline activities that you conduct during lecture & No & 71 & 30 & 35 & 51 \\
\hline $\begin{array}{l}\text { with your cell phone (e.g., web surfing, } \\
\text { checking email, social media) affects your } \\
\text { academic performance? }(\%)^{+}\end{array}$ & $\begin{array}{l}\text { I don't conduct non-class- } \\
\text { related cell phone activities } \\
\text { during lecture }\end{array}$ & 14 & 60 & 17 & 31 \\
\hline 3. Do you think the non-class-related & Yes & 12 & 19 & 30 & 17 \\
\hline activities that a peer in your immediate & No & 83 & 51 & 70 & 70 \\
\hline $\begin{array}{l}\text { vicinity conducts during lecture with their } \\
\text { cell phone affects your academic } \\
\text { performance? (\%)* }\end{array}$ & $\begin{array}{l}\text { My neighbors don't conduct } \\
\text { non-class-related cell phone } \\
\text { activities during lecture }\end{array}$ & 5 & 30 & 0 & 13 \\
\hline 4. Do you think the non-class-related & Yes & 10 & 10 & 17 & 11 \\
\hline activities that you conduct during lecture & No & 75 & 35 & 61 & 58 \\
\hline $\begin{array}{l}\text { with your cell phone may disturb your } \\
\text { peer(s)? (\%)* }\end{array}$ & $\begin{array}{l}\text { I don't conduct non-class- } \\
\text { related cell phone activities } \\
\text { during lecture }\end{array}$ & 14 & 55 & 22 & 30 \\
\hline
\end{tabular}

The results of this study show that students from three academic programmes perceive their exposure to the concept of classroom etiquette during either their South College program or during previous academic experiences in a similar manner (Table II). The results also show differences between students from three healthcare programmes, pharmacy, PA, and nursing, regarding classroom etiquette and their perceptions about it (Table II to Table VI). Some variability shown in the results may be attributed to certain differences between the programmes, such as the nature of the programme, the demographics of student populations, the classroom facilities that each programme uses, and the classroom etiquette expectations as outlined in student handbooks and course syllabi.

The PA programme requires a bachelor's degree as a pre-requisite for admissions into the programme, whereas the pharmacy and nursing programmes do not. The fact that students within the PA programme earned a significantly higher (Table I) academic degree before entering their professional programme may affect their classroom etiquette as well as perceptions about classroom etiquette. This criterion may explain why PA students report a significantly smaller tendency than pharmacy students to arrive late to class or leave the classroom prior to the end of the lecture without returning to the classroom (Table III).

The classrooms provided for the PA and nursing programmes are of sufficient size to seat the number of students in class with the instructor in close proximity to the students. In contrast, the pharmacy students sit in an auditorium with substantially more unoccupied seats, and the instructor stands on a large and elevated stage that is relatively distant from most of the students. In such a classroom, it is anticipated that students may feel that instructors are less likely to notice unprofessional behaviour during lecture. This difference may serve as an additional explanation for the significantly greater tendency of pharmacy students to arrive late to class compared to PA students (Table III). Differences in the physical facilities between the three programmes may also contribute to the significantly greater frequency for pharmacy students to report the instance of a peer-initiated conversation as compared to such reports by PA students or nursing students (Table IV).

A limitation of this study is that it is uncertain that results from this study may be generalized to other academic programmes (Gaudreau et al., 2014) and even to corresponding academic programmes at other institutions. For example, professionalism standards in other programmes and institutions may affect classroom etiquette; and varying student demographics in schools of pharmacy such as those schools that require a bachelor's degree as a prerequisite for admissions into the programme may affect student classroom etiquette and their perceptions about it. Moreover, this study focused on first-year students while it was shown that the perceptions of classroom etiquette may differ at various stages of an academic programme, even within the same institution (Paik \& Broedel-Zaugg, 2006).

Additional limitations that are specific to the study methodology are that responses to some survey questions may have been more accurate by requesting the student responders to record their activities during 
class time; and although the survey instrument underwent multiple reviews, it was not validated by its administration to a group of potential responders (Artino et al., 2014).

Non-class-related activities, including those that involve the use of electronic devices, are undesirable since students reported in this study for pharmacy, PA, and nursing programmes, and the literature also suggests for other academic programmes that such activities may adversely affect student academic performance (Sana et al., 2013; Gaudreau et al., 2014; Aagaard, 2015; Taneja et al., 2015). Non-class-related activities are also not rare, as shown in this study for pharmacy, PA, and nursing programmes, as well as in reports in the literature regarding other academic programmes (Burke et al., 2014; Gaudreau et al., 2014; Aagaard, 2015; Taneja et al., 2015; Clark, 2017). Overall, efforts should be conducted to reduce nonclass-related activities. This goal can be achieved by 1 ) the education of students regarding appropriate classroom etiquette; 2) the construction of respectful classroom environments; 3) the modification of academic demands (Gaudreau et al., 2014); 4) the development of teaching strategies with greater emphasis on student engagement (Wright et al., 2011; Wei et al., 2012; Taneja et al., 2015); or 5) the implementation of active learning approaches in the classroom (Pistilli \& Cain, 2016). Finally, examples of venues that may be used to emphasise to students the importance of following appropriate classroom etiquette include orientation programmes (AlKandari, 2011), student handbooks (Bayer \& Braxton, 2004), courses about professionalism, course syllabi (Damour, 2008; AlKandari, 2011; Baker, Lusk, \& Neuhauser, 2012; Knepp, 2012; Ali \& Smith, 2014; Taneja et al., 2015; Clark, 2017), and through direct discussion during class instruction (AlKandari, 2011; Baker et al., 2012; Clark, 2017).

This study may bring greater awareness among faculty and administration to the issue of classroom etiquette and encourage them to evaluate their policies related to classroom etiquette and/or to better enforce those policies (Flanigan \& Kiewra, 2018). This study may also motivate researchers to study the issue of classroom etiquette and design additional approaches for its enhancement.

\section{Acknowledgements}

The authors thank Drs. Eric J. Dadey and Karen S. Mark from the Department of Pharmaceutical Sciences, South College School of Pharmacy for their constructive comments regarding the manuscript.

\section{References}

Aagaard, J. (2015). Drawn to distraction: A qualitative study of off-task use of educational technology. Comput Educ, 87, 90-97. https://doi.org/10.1016/j.compedu.2015.03.010

Ali, A., \& Smith, D. (2014). Enforcement and effectiveness of rules in dealing with cell phone use in the classroom. Comp Forum, 12(2), 111-117

AlKandari, N. (2011). The level of student incivility: The need of a policy to regulate college student civility. Coll Stud J, 45(2), 257-268

Artino, A. R., Jr., La Rochelle, J. S., Dezee, K. J., \& Gehlbach, H. (2014). Developing questionnaires for educational research: AMEE Guide No 87. Med Teach, 36(6), 463-474. https://doi.org/10.3109/0142159x.2014.889814

Ausbrooks, A. R., Jones, S. H., \& Tijerina, M. S. (2011). Now you see it, now you don't: Faculty and student perceptions of classroom incivility in a social work program. Adv Soc Work, 12(2), 255-275. https://doi.org/10.18060/1932

Baker, W. M., Lusk, E. J., \& Neuhauser, K. L. (2012). On the use of cell phones and other electronic devices in the classroom: Evidence from a survey of faculty and students. J Educ Bus, 87(5), 275-289. https://doi.org/10.1080/08832323.2011.622814

Bayer, A. E., \& Braxton, J. M. (2004). Conclusions and recommendations: Avenues for addressing teaching and learning improprieties. New Dir Teach Learn, 99, 89-95. https://doi.org/10.1002/tl.162

Bos, N., Groenevald, C., van Bruggen, J., \& Brand-Gruwel, S. (2016). The use of recorded lectures in education and the impact on lecture attendance and exam performance. BrJ Educ Technol, 47(5), 906-917. https://doi.org/10.1111/bjet.12300

Burke, L. A., Karl, K., Peluchette, J., \& Evans, W. R. (2014). Student incivility: A domain review. J Manage Educ, 38(2), 160-191. https://doi.org/10.1177/1052562913488112

Clark, K. R. (2017). Student incivility in radiography education. Radiol Technol, 88(6), 590-602

Damour, L. (2008). Establishing classroom etiquette: General rules of classroom conduct. In W. Buskist \& S. F. Davis (Eds.), Handbook of the Teaching of Psychology (pp. 228-232). Malden, MA: Blackwell Publishing. https://doi.org/10.1002/9780470754924.ch39

Emerick, R. E. (1994). A conversation on classroom etiquette in introductory sociology courses. Teach Sociol, 22(4), 341344. https://doi.org/10.2307/1318928

Feldmann, L. J. (2001). Classroom civility is another of our instructor responsibilities. Coll Teach, 49(4), 137-140. https://doi.org/10.1080/87567555.2001.10844595

Flanigan, A. E., \& Kiewra, K. A. (2018). What college instructors can do about student cyber-slacking. Educ Psychol Rev, 30(2), 585-597. https://doi.org/10.1007/s10648-017-9418-2

Gaudreau, P., Miranda, D., \& Gareau, A. (2014). Canadian University students in wireless classrooms: What do they do on their laptops and does it really matter? Comput Educ, 70, 245-255. https://doi.org/10.1016/j.compedu.2013.08.019 
Imazeki, J. (2014). Bring-your-own-device: Turning cell phones into forces for good. J Econon Educ, 45(3), 240-250. https://doi.org/10.1080/00220485.2014.917898

Knepp, K. A. F. (2012). Understanding student and faculty incivility in higher education. J Eff Teach, 12(1), 33-46

Kwiatkowski, A. C., \& Demirbilek, M. (2016). Investigating veterinary medicine faculty perceptions of lecture capture: Issues, concerns, and promises. J Vet Med Educ, 43(3), 302309. https://doi.org/10.3138/jvme.0615-090R1

Ma, S., Steger, D. G., Doolittle, P. E., \& Stewart, A. C. (2018). Improved academic performance and student perceptions of learning through use of a cell phone-based personal response system. J Food Sci Educ, 17(1), 27-32. https://doi.org/10.1111/1541-4329.12131

Miller, A. N., Katt, J. A., Brown, T., \& Sivo, S. A. (2014). The relationship of instructor self-disclosure, nonverbal immediacy, and credibility to student incivility in the college classroom. Commun Educ, 63(1), 116. https://doi.org/10.1080/03634523.2013.835054

Morrissette, P. J. (2001). Reducing incivility in the university/college classroom. Int Electron J Leadership Learn, 5(4), 1-12

O'Callaghan, F. V., Neumann, D. L., Jones, L., \& Creed, P. A. (2017). The use of lecture recordings in higher education: A review of institutional, student, and lecturer issues. Educ Inf Technol, 22(1), 399-415. https://doi.org/10.1007/s10639015-9451-z

Paik, C., \& Broedel-Zaugg, K. (2006). Pharmacy students' opinions on civility and preferences regarding professors. Am J Pharm Educ, 70(4 Article 88), 1-9. https://doi.org/10.5688/aj700488

Pistilli, N., \& Cain, J. (2016). Using a health care practice framework to address smartphone use in the classroom. Curr Pharm Teach Learn, 8(2), 247-253. https://doi.org/10.1016/j.cptl.2015.12.020

Sana, F., Weston, T., \& Cepeda, N. J. (2013). Laptop multitasking hinders classroom learning for both users and nearby peers. Comput Educ, 62, 24-31. https://doi.org/10.1016/j.compedu.2012.10.003

Spallek, H., \& von Bergmann, H. (2014). Should laptops be allowed in the classroom? Two viewpoints. J Dent Educ, 78(12), 1580-1588. https://doi.org/10.1002/j.0022-0337.2014.78.12.tb05835.x

Spies, A. R. (2010). Use of laptops and other technology in the classroom. Am J Pharm Educ, 74(8 Article 152), 1-2. https://doi.org/10.5688/aj7408152

Suplee, P. D., Lachman, V. D., Siebert, B., \& Anselmi, K. K. (2008). Managing nursing student incivility in the classroom, clinical setting, and online. J Nurs Law, 12(2), 68-77. https://doi.org/10.1891/1073-7472.12.2.68

Taneja, A., Fiore, V., \& Fischer, B. (2015). Cyber-slacking in the classroom: Potential for digital distraction in the new age. Comput Educ, 82, 141-151. https://doi.org/10.1016/j.compedu.2014.11.009

Tom, G. (1998). Faulty and student perceptions of classroom etiquette. J Coll Student Dev, 39(5), 515-517

Wei, F. Y. F., Wang, Y. K., \& Klausner, M. (2012). Rethinking college students' self-regulation and sustained attention: Does text messaging during class influence cognitive learning? Commun Educ, 61(3), 185-204. https://doi.org/10.1080/03634523.2012.672755
Wright, R., Perry, P. J., \& Barnett, M. J. (2011). In reply to "Why we banned use of laptops and 'scribe notes' in our classroom". Am J Pharm Educ, 75(2 Article 38), 1-3. https://doi.org/10.5688/ajpe75238b

Ziefle, K. (2018). Incivility in nursing education: Generational differences. Teach Learn Nurs, 13(1), 27-30. https://doi.org/10.1016/j.teln.2017.09.004 